(c) American Dairy Science Association, 2005.

\title{
Milk Production and Nitrogen Excretion of Dairy Cows Fed Different Amounts of Protein and Varying Proportions of Alfalfa and Corn Silage
}

\author{
E. B. Groff and Z. Wu \\ Department of Dairy and Animal Science, Pennsylvania State University, University Park 16802
}

\section{ABSTRACT}

Four trials were conducted to determine the effect of dietary protein amount on lactation performance and $\mathrm{N}$ utilization. Each trial used one of the following alfalfa-to-corn-silage ratios for the forage part of the diet: 100:0, 75:25, 50:50, and 25:75. All trials utilized 16 midlactation Holstein cows (days in milk averages ranging from 80 to 140 among trials) in a replicated $4 \times 4$ Latin square design with 3 -wk periods, including 2 wk for adaptation and $1 \mathrm{wk}$ for data collection. Diets consisted of 50\% forage and 50\% concentrate (dry matter basis) and were formulated to contain 15.00, 16.25, 17.50, or $18.75 \%$ protein in each trial. The analyzed protein content of the diets was $15.7,16.9,18.0$, and $19.2 \%$ when averaged across trials. Milk yield was similar among dietary protein levels in each trial, ranging from 35.2 to $36.1 \mathrm{~kg} / \mathrm{d}$ when data were combined across trials. Changes in milk fat and protein due to the protein content of the diet were small and inconsistent. Both milk urea nitrogen and blood urea nitrogen concentrations increased linearly as the protein content of the diet was increased, ranging from 9.9 to 13.1 and from 9.9 to $13.8 \mathrm{mg} / \mathrm{dL}$, respectively, across trials. As dietary protein was increased from the lowest to the highest concentrations when data were combined and analyzed, mean fecal $\mathrm{N}$ concentration increased from 2.8 to $3.0 \%$, and urinary $\mathrm{N}$ from 5.8 to $7.3 \mathrm{~g} / \mathrm{L}$. At the same time, mean total $\mathrm{N}$ excretion increased from 484 to $571 \mathrm{~g} / \mathrm{d}$, and conversion of intake $\mathrm{N}$ to milk $\mathrm{N}$ decreased from 0.27 to 0.22 , resulting in an average change of $18 \%$. Of the $\mathrm{N}$ excreted, urinary $\mathrm{N}$ accounted for an increasing proportion, ranging from 41 to $48 \%$, as dietary protein was increased. Overall, based on $\mathrm{N}$ utilization as well as milk production, $17 \%$ protein in diets utilizing various proportions of alfalfa and corn silage as the forage source appeared sufficient for cows producing $38 \mathrm{~kg} / \mathrm{d}$ of milk in this study.

(Key words: dairy cow, dietary protein, nitrogen excretion, forage)

Received January 18, 2005.

Accepted June 9, 2005.

Corresponding author: Z. Wu; e-mail: ziw1@psu.edu.

\section{INTRODUCTION}

Recently, there has been an effort to reduce the amount of protein fed to dairy cows to minimize N excretion and loss to the environment. Several studies (Leonardi et al., 2003; Wattiaux and Karg, 2004a) compared "low" and "high" dietary protein amounts and suggested that it is possible to reduce protein from 18 (or above) to $16.5 \%$ without affecting milk production. However, other studies observed decreased milk production when dietary protein was reduced from 17.4 to $15.2 \%$ (Kalscheur et al., 1999) and from 18.4 to $15.1 \%$ (Broderick, 2003). Wu and Satter (2000) suggested that dietary protein may only be reduced moderately from levels producers often use ( $18 \%)$ without affecting milk production, and that other means including maximizing microbial protein production are needed to obtain a significant reduction in the need of dietary protein, and therefore a reduction in $\mathrm{N}$ excretion. More research is needed to define the response curve for milk production as a function of dietary protein amount.

In addition to protein intake, the type of forage fed may be important. Alfalfa and corn silage are the two most common forages fed to dairy cows in the United States. The 2 feedstuffs complement each other by providing fermentable energy and available $\mathrm{N}$ for microbial protein synthesis in the rumen. Hence, the proportions of these forage sources in the diet could have an influence on N utilization. Dhiman and Satter (1997) showed that the efficiency of $\mathrm{N}$ utilization increased as the proportion of corn silage was increased to two-thirds in its combination with alfalfa. Wattiaux and Karg (2004a) showed increased milk yields when the corn silage proportion was raised from 25 to $75 \%$ in dietary forage that utilized alfalfa silage and corn silage only.

The objective of this study was to determine the response in milk production and $\mathrm{N}$ excretion in dairy cows to dietary protein amount for diets that varied in the proportion of alfalfa and corn silage.

\section{MATERIALS AND METHODS}

\section{Experimental Design}

Four trials were conducted with the approval of the Pennsylvania State University Animal Care and Use 
Table 1. Ingredient and nutrient composition of diets (trial 1, alfalfa:corn silage ratio = 100:0).

\begin{tabular}{|c|c|c|c|c|}
\hline \multirow[b]{2}{*}{ Item } & \multicolumn{4}{|c|}{ Dietary treatment (CP \%) } \\
\hline & 15.00 & 16.25 & 17.50 & 18.75 \\
\hline \multicolumn{5}{|l|}{ Ingredient, \% of DM } \\
\hline Alfalfa silage & 50.00 & 50.00 & 50.00 & 50.00 \\
\hline Soyhulls & 2.88 & 2.88 & 2.88 & 2.88 \\
\hline Corn, ground & 42.03 & 39.19 & 36.53 & 33.87 \\
\hline Soybeans, roasted & 2.12 & 3.08 & 3.46 & 4.04 \\
\hline Soybean meal, $48 \% \mathrm{CP}$ & - & 1.92 & 4.23 & 6.35 \\
\hline Protein mix ${ }^{1}$ & 1.88 & 1.88 & 1.88 & 1.88 \\
\hline Monosodium phosphate & 0.42 & 0.38 & 0.35 & 0.31 \\
\hline Sodium bicarbonate & 0.67 & 0.67 & 0.67 & 0.67 \\
\hline \multicolumn{5}{|c|}{ Nutrient composition based on formulation } \\
\hline RUP, \% of $\mathrm{CP}^{2}$ & 35.3 & 35.4 & 35.3 & 35.2 \\
\hline Soluble protein, $\%$ of $\mathrm{CP}^{3}$ & 32.9 & 31.9 & 31.2 & 30.6 \\
\hline $\mathrm{NFC}, \%$ of $\mathrm{DM}^{3}$ & 48.2 & 47.0 & 45.8 & 44.7 \\
\hline $\mathrm{NE}_{\mathrm{L}}, \mathrm{Mcal} / \mathrm{kg}^{2}$ & 1.64 & 1.64 & 1.64 & 1.64 \\
\hline $\mathrm{Na}, \%$ of $\mathrm{DM}^{3}$ & 0.29 & 0.27 & 0.27 & 0.26 \\
\hline $\mathrm{K}, \%$ of $\mathrm{DM}^{3}$ & 1.04 & 1.09 & 1.14 & 1.19 \\
\hline \multicolumn{5}{|c|}{ Nutrient composition based on analysis, $\%$ of DM } \\
\hline $\mathrm{CP}$ & 16.6 & 17.7 & 18.9 & 20.0 \\
\hline $\mathrm{NDF}$ & 27.9 & 27.9 & 27.9 & 27.9 \\
\hline $\mathrm{ADF}$ & 20.9 & 21.1 & 21.3 & 21.5 \\
\hline
\end{tabular}

\footnotetext{
${ }^{1} \mathrm{~A}$ mixture of equal proportions of feather meal, bone meal, and fish meal (Pro Base; Agway Feed and Nutrition, Shippensburg, PA). The mix was added with trace minerals and vitamins and each kilogram contained $92 \mathrm{mg}$ of $\mathrm{Ca}, 98 \mathrm{mg}$ of $\mathrm{Mg}, 26 \mathrm{mg}$ of Co, $777 \mathrm{mg}$ of Cu, $52 \mathrm{mg}$ of I, $773 \mathrm{mg}$ of Fe, $2324 \mathrm{mg}$ of $\mathrm{Mn}$, $2.3 \mathrm{mg}$ of Se, $2336 \mathrm{mg}$ of $\mathrm{Zn}, 346,000 \mathrm{IU}$ of vitamin A, 86,500 IU of vitamin D, and $2163 \mathrm{IU}$ of vitamin E. ${ }^{2}$ Calculated using the Spartan program of Michigan State University.

${ }^{3}$ Calculated using the Cornell Net Carbohydrate and Protein Systems program.
}

Committee. In each trial, 16 multiparous Holstein cows were used to determine the effect of varying the dietary protein content on milk production and $\mathrm{N}$ excretion. Cows averaged $146 \pm 40,80 \pm 18,100 \pm 15$, and $105 \pm$ $17 \mathrm{DIM}$ at the beginning of experiment, and 29,040 \pm $2900,30,050 \pm 4030,29,640 \pm 3070$, and 27,930 \pm 4520 $\mathrm{kg}$ in previous 305 milk equivalent, for trials 1 to 4 , respectively. Each trial utilized a $4 \times 4$ Latin square design with 3 -wk periods and 4 replicates. The first 2 wk of each period were used as an adjustment period, and the last week for data collection. Cows were blocked and placed in the same square based on similarity in DIM, milk yield during the $2 \mathrm{wk}$ before the trial, and parity.

\section{Diets}

Diets (Tables 1 to 4) used in all trials consisted of forage and concentrate at a ratio of 50:50 (DM basis). Alfalfa silage and corn silage were the forage sources used in the trials. Each trial used a different alfalfa:corn silage ratio, and these ratios were 100:0, 75:25, 50:50, and 25:50 for trials $1,2,3$, and 4, respectively. The concentrate portion of the diets was similar for all trials and consisted of roasted soybeans, soybean meal, ground corn, and a protein mix consisting of equal proportions of feather meal, fishmeal, and bone meal (Pro Base; Agway Feed and Nutrition, Shippensburg, PA).
The targeted protein content of the diet was 15.00 , $16.25,17.50$, or $18.75 \%$ for the 4 treatments in each trial. Diets were formulated to be similar in $\mathrm{NE}_{\mathrm{L}}$ within trials (ranging from 1.64 to $1.71 \mathrm{Mcal} / \mathrm{kg}$ among trials) and in the proportion of CP as RUP and soluble protein. Across trials, as the alfalfa:corn silage ratio was varied, the proportions of corn, soybeans, soybean meal, and the protein mix were adjusted to maintain similar protein and energy concentrations. Calculated NFC content of the diet was slightly higher for trials 1 and 2 than for trials 3 and 4 , and the $\mathrm{NE}_{\mathrm{L}}$ content was lowest for trial 1 and highest for trial 4 .

\section{Management and Sampling}

Cows were housed in a tie-stall barn and fed a TMR at $0800 \mathrm{~h}$. Diets were offered ad libitum and orts were kept at $10 \%$ of the amount offered. The actual amounts of feed offered and refused were recorded daily to obtain net intake for individual animals. Cows were milked at 0500 and $1700 \mathrm{~h}$ and were placed in an exercise lot for $1 \mathrm{~h}$ before each milking. Cows were not treated with bST.

Samples of TMR and forages were taken daily, frozen, and pooled weekly. Concentrate components were collected once every period. The diets were adjusted (asfed basis) weekly based on ingredient DM. The BW of cows was measured on 2 consecutive days at the 
Table 2. Ingredient and nutrient composition of diets (trial 2, alfalfa:corn silage ration = 75:25).

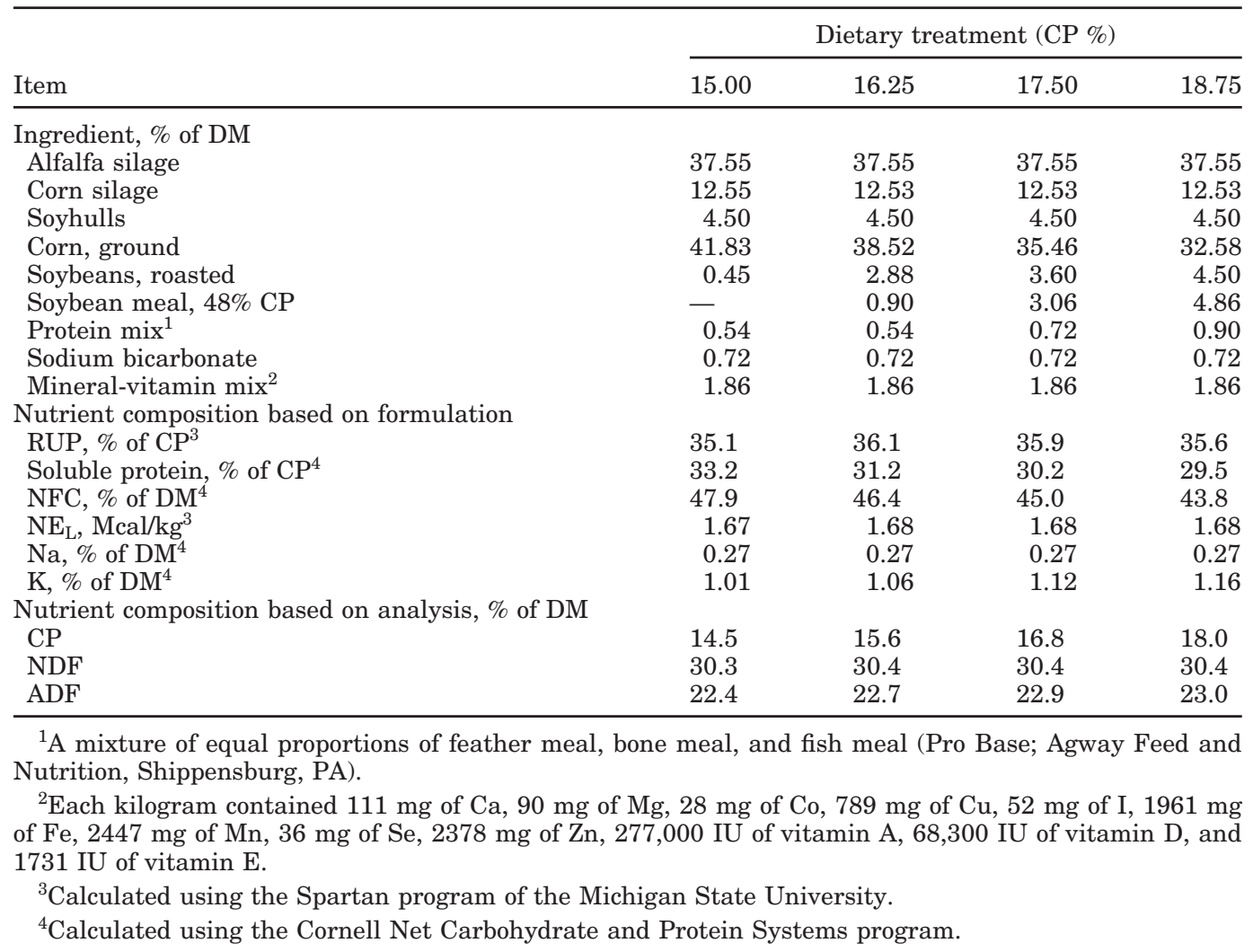

beginning of the trial and at the end of each period. Milk weights were recorded at each milking using the milking system (S.A.E. Afikim System, Jordan Valley, Israel). Two milk samples were taken from consecutive a.m. and p.m. milkings during the last day in each period. Fecal and urine samples were taken at 0900 and $1530 \mathrm{~h}$ during the last $4 \mathrm{~d}$ of the collection week of each period. Feces were sampled from the rectum and urine during urination with stimulation. Fecal samples were pooled to obtain a composite for individual cows in each period. Samples of urine were acidified to $\mathrm{pH}$ $<4$ using $4 M \mathrm{HCl}$, and frozen. These samples were later thawed and a composite was generated for each cow during each period. Blood samples $(10 \mathrm{~mL})$ were collected once during the collection week at approximately $1530 \mathrm{~h}$ from the coccygeal vein into evacuated tubes containing EDTA.

\section{Analyses and Measurements}

Milk samples were analyzed for fat, protein, lactose, urea N, and SCC by the Pennsylvania DHIA Laboratory (University Park, PA) using infrared spectroscopy (Fossmatic 400 Milk-Scan; Foss Electric, Hillerød, Denmark); SNF was calculated as total solids minus fat.
Feed and fecal samples were dried at $55^{\circ} \mathrm{C}$ in a forcedair oven for $48 \mathrm{~h}$ and ground through a 1-mm screen (Wiley Mill, Arthur H. Thomas, Philadelphia, PA). Ground samples were analyzed for DM $\left(102^{\circ} \mathrm{C}\right), \mathrm{CP}$ based on Kjeldahl N (AOAC, 1990), and NDF and ADF (Ankom $^{200}$ Fiber Analyzer, Ankom Technology Corp., Fairport, NY). Urine samples were also analyzed for $\mathrm{CP}$ using the AOAC method (AOAC, 1990). Chemical analyses of feeds and feces were based on DM measurements made at $102^{\circ} \mathrm{C}$. Nutrient content of TMR was computed from the average nutrient content of the individual ingredients analyzed using the samples taken.

Nutrient digestibility was estimated using the marker technique with indigestible ADF (Huhtanen et al., 1994). The TMR and fecal samples were weighed $(0.35 \mathrm{~g})$ into $5 \times 10 \mathrm{~cm}$ Dacron bags with $50-\mu \mathrm{m}$ pores (No. R510; Ankom Technology) and incubated in the rumen of a cannulated cow fed a diet containing $60 \%$ forage and $40 \%$ concentrate for $12 \mathrm{~d}$ for indigestible $\mathrm{ADF}$ determination. Apparent digestibility of nutrients was estimated based on the concentration of indigestible ADF in TMR and feces, and $\mathrm{N}$ excretion in feces was calculated from the thus obtained digestibility for $\mathrm{N}$ and fecal $\mathrm{N}$ concentration.

Blood plasma was obtained by centrifugation at $4^{\circ} \mathrm{C}$ and $3000 \times g$ for $15 \mathrm{~min}$, and analyzed for urea $\mathrm{N}$ concen- 
Table 3. Ingredient and nutrient composition of diets (trial 3, alfalfa:corn silage ratio $=50: 50$ ).

\begin{tabular}{|c|c|c|c|c|}
\hline \multirow[b]{2}{*}{ Item } & \multicolumn{4}{|c|}{ Dietary treatment (CP \%) } \\
\hline & 15.00 & 16.25 & 17.50 & 18.75 \\
\hline \multicolumn{5}{|l|}{ Ingredient, \% of DM } \\
\hline Alfalfa silage & 25.02 & 25.02 & 25.02 & 25.02 \\
\hline Corn silage & 25.02 & 25.02 & 25.02 & 25.02 \\
\hline Soyhulls & 7.00 & 7.00 & 7.00 & 7.00 \\
\hline Corn, ground & 30.74 & 27.90 & 25.13 & 22.35 \\
\hline Soybeans, roasted & 1.99 & 2.79 & 3.69 & 4.48 \\
\hline Soybean meal, $48 \% \mathrm{CP}$ & 6.57 & 8.65 & 10.56 & 12.59 \\
\hline Protein $\operatorname{mix}^{1}$ & 0.60 & 0.60 & 0.60 & 0.60 \\
\hline Monosodium phosphate & 0.38 & 0.34 & 0.30 & 0.26 \\
\hline Sodium bicarbonate & 0.70 & 0.70 & 0.70 & 0.70 \\
\hline Mineral-vitamin $\operatorname{mix}^{2}$ & 1.98 & 1.98 & 1.98 & 1.98 \\
\hline \multicolumn{5}{|c|}{ Nutrient composition based on formulation } \\
\hline RUP, $\%$ of $\mathrm{CP}^{3}$ & 36.0 & 36.0 & 36.0 & 36.0 \\
\hline Soluble protein, $\%$ of $\mathrm{CP}^{4}$ & 29.2 & 28.5 & 27.8 & 27.3 \\
\hline $\mathrm{NFC}, \%$ of $\mathrm{DM}^{4}$ & 45.9 & 44.7 & 43.5 & 42.3 \\
\hline $\mathrm{NE}_{\mathrm{L}}, \mathrm{Mcal} / \mathrm{kg}^{3}$ & 1.68 & 1.69 & 1.69 & 1.69 \\
\hline $\mathrm{Na}, \%$ of $\mathrm{DM}^{4}$ & 0.33 & 0.33 & 0.32 & 0.32 \\
\hline $\mathrm{K}, \%$ of $\mathrm{DM}^{4}$ & 1.10 & 1.15 & 1.20 & 1.25 \\
\hline \multicolumn{5}{|c|}{ Nutrient composition based on analysis, $\%$ of DM } \\
\hline $\mathrm{CP}$ & 15.7 & 16.9 & 17.9 & 19.0 \\
\hline $\mathrm{NDF}$ & 30.5 & 30.6 & 30.8 & 30.9 \\
\hline $\mathrm{ADF}$ & 20.2 & 20.4 & 20.6 & 20.8 \\
\hline
\end{tabular}

${ }^{1} \mathrm{~A}$ mixture of equal proportions of feather meal, bone meal, and fish meal (Pro Base; Agway Feed and Nutrition, Shippensburg, PA).

${ }^{2}$ Each kilogram of the mix contained $193 \mathrm{mg}$ of Ca, $64 \mathrm{mg}$ of $\mathrm{Mg}, 20 \mathrm{mg}$ of $\mathrm{Co}, 600 \mathrm{mg}$ of Cu, $40 \mathrm{mg}$ of I, $150 \mathrm{mg}$ of Fe, $1800 \mathrm{mg}$ of Mn, $15 \mathrm{mg}$ of Se, $1800 \mathrm{mg}$ of Zn, 265,000 IU of vitamin A, 66,100 IU of vitamin $\mathrm{D}$, and $1653 \mathrm{IU}$ of vitamin $\mathrm{E}$.

${ }^{3}$ Calculated using the Spartan program of the Michigan State University.

${ }^{4}$ Calculated using the Cornell Net Carbohydrate and Protein Systems program.

tration (Stanbio Urea Nitrogen kit 580; Stanbio Laboratory, Inc., San Antonio, TX). Urine samples were analyzed for creatinine concentration (Sigma Creatinine Kit 555; Sigma Diagnostics, Inc., St. Louis, MO) to estimate urine volume using the method described by Valadares et al. (1999). Urinary creatinine excretion is considered proportional to lean body mass (Oser, 1965), unaffected by diets (Valadares et al., 1999, using diets consisting of 35 to $80 \%$ alfalfa silage and 65 to $20 \%$ concentrate). Daily excretion of urinary creatinine also is relatively constant (Susmel et al., 1994; Vagnoni et al., 1997). This method has been shown to be satisfactory in accuracy, as evaluated by comparison with total collection (Valadares et al., 1999; Leonardi et al., 2003).

\section{Statistical Analyses}

Data were analyzed separately for each trial with a $4 \times 4$ replicated Latin square design. The MIXED procedure of SAS (SAS Institute, 1999) with a repeated measurement statement was used for the analysis using the following model:

$$
\mathrm{Y}=\mu+\mathrm{sq}+\mathrm{p}+\mathrm{cp}+\mathrm{e}
$$

where $\mathrm{Y}=$ observation, $\mu=$ overall mean, $\mathrm{sq}=$ square, $\mathrm{p}=$ period, $\mathrm{cp}=$ dietary $\mathrm{CP}$ amount, and $\mathrm{e}=$ residual error. The repeated measurements statement was cow within square.

Covariance structures of unstructured analysis, antedependence, autoregressive order one, and compound symmetry were used in the analysis, and a specific structure was chosen for reporting with the log likelihood ratio test using $\chi^{2}$ tables. Overall treatment differences were examined using least squares means. Treatment effects were tested for linear, quadratic, and cubic relationships. For all analyses, differences were considered significant at $P<0.05$, unless specified.

\section{RESULTS AND DISCUSSION}

\section{Diet Composition}

The protein content of the diets was higher than formulated for trials 1 and 4, lower than formulated for trial 2, and similar to formulated for trial 3 (Tables 1 to 4). Alfalfa silage and soybean meal used were slightly higher in protein in trials 1 and 4 than in trials 2 and 3 (Table 5), contributing to the differences in dietary protein among trials and between the analyzed and 
Table 4. Ingredient and nutrient composition of diets (trial 4, alfalfa:corn silage ratio $=25: 75$ ).

\begin{tabular}{|c|c|c|c|c|}
\hline \multirow[b]{2}{*}{ Item } & \multicolumn{4}{|c|}{ Dietary treatment (CP \%) } \\
\hline & 15.00 & 16.25 & 17.50 & 18.75 \\
\hline \multicolumn{5}{|l|}{ Ingredient, $\%$ of DM } \\
\hline Alfalfa silage & 12.50 & 12.50 & 12.50 & 12.50 \\
\hline Corn silage & 37.49 & 37.49 & 37.49 & 37.49 \\
\hline Soyhulls & 6.58 & 6.58 & 6.58 & 6.14 \\
\hline Corn, ground & 27.88 & 25.18 & 22.68 & 20.26 \\
\hline Soybeans, roasted & 0.90 & 1.20 & 2.33 & 2.87 \\
\hline Soybean meal, $48 \% \mathrm{CP}$ & 10.40 & 12.56 & 14.17 & 16.25 \\
\hline Protein $\operatorname{mix}^{1}$ & 0.54 & 0.82 & 0.82 & 0.90 \\
\hline Monosodium phosphate & 0.32 & 0.28 & 0.24 & 0.20 \\
\hline Sodium bicarbonate & 0.70 & 0.70 & 0.70 & 0.70 \\
\hline Mineral-vitamin $\operatorname{mix}^{2}$ & 2.69 & 2.69 & 2.69 & 2.69 \\
\hline \multicolumn{5}{|c|}{ Nutrient composition based on analysis } \\
\hline RUP, \% of $\mathrm{CP}^{3}$ & 36.8 & 36.8 & 36.8 & 36.7 \\
\hline Soluble protein, \% of $\mathrm{CP}^{4}$ & 28.5 & 27.8 & 27.0 & 26.5 \\
\hline $\mathrm{NFC}, \%$ of $\mathrm{DM}^{4}$ & 45.9 & 44.6 & 43.4 & 42.3 \\
\hline NEL, Mcal/ $/ \mathrm{kg}^{3}$ & 1.71 & 1.70 & 1.71 & 1.71 \\
\hline $\mathrm{Na}, \%$ of $\mathrm{DM}^{4}$ & 0.34 & 0.33 & 0.33 & 0.32 \\
\hline $\mathrm{K}, \%$ of $\mathrm{DM}^{4}$ & 1.08 & 1.13 & 1.17 & 1.22 \\
\hline \multicolumn{5}{|c|}{ Nutrient composition based on formulation, \% of DM } \\
\hline $\mathrm{CP}$ & 16.2 & 17.5 & 18.6 & 19.8 \\
\hline NDF & 29.3 & 29.3 & 29.3 & 29.2 \\
\hline $\mathrm{ADF}$ & 18.0 & 18.1 & 18.3 & 18.3 \\
\hline
\end{tabular}

${ }^{1} \mathrm{~A}$ mixture of equal proportions of feather meal, bone meal and fish meal (Pro Base; Agway Feed and Nutrition, Shippensburg, PA).

${ }^{2}$ Each kilogram of the mix contained $193 \mathrm{mg}$ of Ca, $64 \mathrm{mg}$ of $\mathrm{Mg}, 20 \mathrm{mg}$ of Co, $600 \mathrm{mg}$ of $\mathrm{Cu}, 40 \mathrm{mg}$ of I, $150 \mathrm{mg}$ of Fe, $1800 \mathrm{mg}$ of Mn, $15 \mathrm{mg}$ of Se, $1800 \mathrm{mg}$ of Zn, 265,000 IU of vitamin A, 66,100 IU of vitamin $\mathrm{D}$, and $1653 \mathrm{IU}$ of vitamin $\mathrm{E}$.

${ }^{3}$ Calculated using the Spartan program of the Michigan State University.

${ }^{4}$ Calculated using the Cornell Net Carbohydrate and Protein Systems program.

Table 5. Analyses of dietary ingredients. ${ }^{1}$

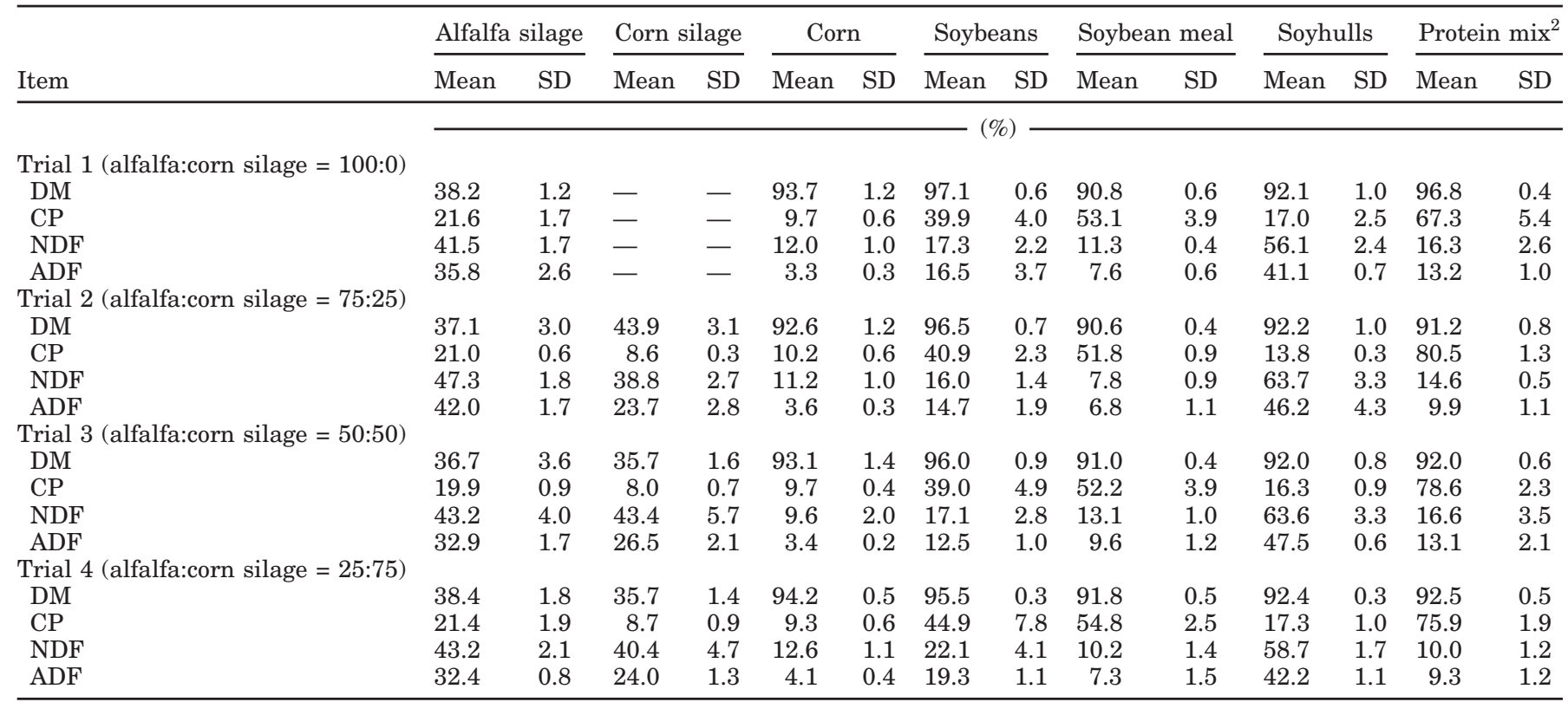

${ }^{1} \mathrm{n}=12$ for alfalfa silage and corn silage, and $\mathrm{n}=4$ for other ingredients.

${ }^{2}$ Pro Base (Agway Feed and Nutrition, Shippensburg, PA). 
Table 6. Dry matter intake and BW of cows fed diets containing different amounts of protein in trials utilizing different ratios of alfalfa to corn silage.

\begin{tabular}{|c|c|c|c|c|c|c|}
\hline \multirow[b]{2}{*}{ Item } & \multicolumn{4}{|c|}{ Dietary treatment $(\mathrm{CP} \%)$} & \multirow[b]{2}{*}{ SEM } & \multirow[b]{2}{*}{ Effect } \\
\hline & 15.00 & 16.25 & 17.50 & 18.75 & & \\
\hline \multicolumn{7}{|c|}{ Trial 1 (alfalfa:corn silage ratio $=100: 0$ ) } \\
\hline DMI, kg/d & 22.9 & 23.3 & 22.6 & 23.2 & 0.6 & NS \\
\hline $\mathrm{BW}, \mathrm{kg}$ & 727 & 724 & 728 & 729 & - & - \\
\hline BW change, g/d & 481 & 735 & 318 & 544 & 174 & NS \\
\hline \multicolumn{7}{|c|}{ Trial 2 (alfalfa:corn silage ratio $=75: 25$ ) } \\
\hline DMI, kg/d & 28.7 & 27.9 & 30.2 & 29.3 & 0.7 & $\mathrm{~L}, \mathrm{C}$ \\
\hline $\mathrm{BW}, \mathrm{kg}$ & 682 & 674 & 683 & 677 & - & - \\
\hline BW change, g/d & -48 & 395 & 102 & 757 & 346 & NS \\
\hline \multicolumn{7}{|c|}{ Trial 3 (alfalfa:corn silage ratio $=50: 50$ ) } \\
\hline DMI, kg/d & 24.2 & 24.7 & 23.9 & 24.9 & 0.5 & NS \\
\hline $\mathrm{BW}, \mathrm{kg}$ & 682 & 680 & 681 & 672 & - & - \\
\hline BW change, $\mathrm{g} / \mathrm{d}$ & 395 & 97 & 256 & 628 & 193 & NS \\
\hline \multicolumn{7}{|c|}{ Trial 4 (alfalfa:corn silage ratio $=25: 75$ ) } \\
\hline DMI, kg/d & 25.8 & 26.4 & 25.9 & 25.7 & 0.8 & NS \\
\hline $\mathrm{BW}, \mathrm{kg}$ & 745 & 744 & 743 & 748 & - & - \\
\hline BW change, g/d & 521 & 551 & 430 & 281 & 291 & NS \\
\hline
\end{tabular}

${ }^{1} \mathrm{NS}=$ Not significant $(P>0.05), \mathrm{L}=$ linear effect, $\mathrm{C}=$ cubic effect, all at $P<0.01$.

formulated concentrations. The protein content of soybeans was high in trial 4 , and the content of soyhulls was low in trial 2 (Table 5), also contributing to the differences. However, the differentiation in dietary protein among treatments in each trial remained (Tables 1 to 4 ), and the increment (approximately 1.2\%) was consistent with the targeted differences. The analyzed dietary protein was $15.7,16.9,18.0$, and $19.2 \%$ for the treatments when averaged across trials, compared to the target concentrations of $15.00,16.25,17.50$, and $18.75 \%$.

\section{Lactation Performance}

Dry matter intake was not affected by dietary protein concentration in any of the trials except for trial 2 , in which linear and quadratic effects were observed (Table 6). These effects, however, were small. Broderick (2003) showed similarly small increases in DMI as dietary protein was increased from 15.1 to $18.4 \%$, whereas no change was reported by Davidson et al. (2003) with dietary protein ranging from 16.5 to $19.4 \%$ or by Wattiaux and Karg (2004a) using protein of 16.5 to $17.9 \%$. Overall, DMI appeared high for trial 2 compared with the other trials. Cows used in trial 2 were earlier in stage of lactation, and the experiment was conducted from September to early December compared with April to September for the other trials. Cooler ambient temperatures during the later season of the year might have contributed to the higher feed intake in trial 2 . The BW of cows was similar among treatments in all trials, although there was large animal variation. Most groups of cows gained BW during experiments, as they were in mid lactation.
There was no effect of dietary protein concentration on milk yield in any of the trials except for trial 2 , in which a tendency $(P<0.10)$ for a linear response to increased dietary protein was observed (Table 7). When data from all trials were combined, statistical analysis using a model that included trial and its interaction with dietary protein showed no overall effect of dietary protein on milk yield, with means ranging from 35.2 to $36.1 \mathrm{~kg} / \mathrm{d}$ (SEM 0.8) for the 4 treatments. The lack of response in milk production is consistent with others' observations that milk yield did not change when dietary protein was varied from 17.2 to $19.0 \%$ (Sannes et al., 2002), from 16.8 to $19.4 \%$ (Davidson et al., 2003), and from 16.7 to $18.4 \%$ (Broderick, 2003) for cows producing 34 to $35 \mathrm{~kg} / \mathrm{d}$. However, milk yield increased from 46 to $49 \mathrm{~kg} / \mathrm{d}$ when dietary protein was increased from 16.5 to $19.4 \%$ in the study of Wattiaux and Karg (2004a) using cows around peak lactation. In the study of Broderick (2003), milk yield decreased when dietary protein was reduced to $15.1 \%$. It seems that milk production benefits from $>15 \%$ protein, but increasing protein above $17 \%$ has no further effect, unless production is exceptionally high, such as that of high-producing cows during peak lactation.

Milk fat content changed with dietary protein in a linear and cubic manner in trial 1 , and a quadratic fashion in trial 3 , but did not change in the other trials (Table 7). Although milk fat yield and 3.5\% FCM increased linearly with dietary protein in trial 2 and changed in a cubic manner in trial 4 , these measurements did not vary in trial 1 or 3 . Milk protein content did not change in any of the trials except for trial 4 , in which a linear and quadratic response was observed, associated with some small differences among treat- 
Table 7. Milk yield and components of cows fed diets containing different amounts of protein in trials utilizing different ratios of alfalfa to corn silage.

\begin{tabular}{|c|c|c|c|c|c|c|}
\hline \multirow[b]{2}{*}{ Item } & \multicolumn{4}{|c|}{ Dietary treatment (CP \%) } & \multirow[b]{2}{*}{ SEM } & \multirow[b]{2}{*}{ Effect $^{1}$} \\
\hline & 15.00 & 16.25 & 17.50 & 18.75 & & \\
\hline \multicolumn{7}{|c|}{ Trial 1 (alfalfa:corn silage ratio $=100: 0)$} \\
\hline Milk, kg/d & 31.5 & 32.0 & 32.2 & 32.5 & 1.2 & NS \\
\hline Fat, \% & 3.93 & 3.61 & 3.79 & 3.61 & 0.11 & $\mathrm{~L}, \mathrm{C}$ \\
\hline Fat yield, kg/d & 1.216 & 1.131 & 1.210 & 1.209 & 0.060 & NS \\
\hline $3.5 \% \mathrm{FCM}, \mathrm{kg} / \mathrm{d}$ & 33.3 & 32.2 & 33.5 & 33.6 & 1.4 & NS \\
\hline Protein, \% & 3.16 & 3.12 & 3.17 & 3.10 & 0.05 & NS \\
\hline Protein, kg/d & 0.989 & 0.997 & 1.019 & 1.001 & 0.041 & NS \\
\hline Lactose, \% & 4.57 & 4.61 & 4.62 & 4.66 & 0.07 & NS \\
\hline $\mathrm{SNF}, \%$ & 8.53 & 8.53 & 8.59 & 8.56 & 0.09 & NS \\
\hline $\mathrm{SCC}, 1000 / \mathrm{mL}$ & 301 & 366 & 739 & 201 & 226 & NS \\
\hline \multicolumn{7}{|c|}{ Trial 2 (alfalfa:corn silage ratio $=75: 25$ ) } \\
\hline Milk, kg/d & 34.7 & 34.9 & 35.8 & 36.5 & 1.4 & $\mathrm{~L}^{2}$ \\
\hline Fat, \% & 3.52 & 3.57 & 3.53 & 3.56 & 0.15 & NS \\
\hline Fat yield, kg/d & 1.196 & 1.239 & 1.273 & 1.343 & 0.085 & $\mathrm{~L}$ \\
\hline $3.5 \%$ FCM, kg/d & 34.4 & 35.2 & 36.1 & 37.6 & 1.8 & $\mathrm{~L}$ \\
\hline Protein, \% & 3.06 & 3.01 & 3.03 & 3.03 & 0.08 & NS \\
\hline Protein, kg/d & 1.052 & 1.017 & 1.082 & 1.105 & 0.040 & $\mathrm{~L}, \mathrm{C}$ \\
\hline Lactose, \% & 4.72 & 4.75 & 4.71 & 4.70 & 0.08 & NS \\
\hline $\mathrm{SNF}, \%$ & 8.59 & 8.57 & 8.52 & 8.53 & 0.14 & NS \\
\hline $\mathrm{SCC}, 1000 / \mathrm{mL}$ & 377 & 436 & 728 & 798 & 268 & NS \\
\hline \multicolumn{7}{|c|}{ Trial 3 (alfalfa:corn silage ratio $=50: 50)$} \\
\hline Milk, kg/d & 36.4 & 36.8 & 35.8 & 36.8 & 1.1 & NS \\
\hline Fat, $\%$ & 3.26 & 3.37 & 3.30 & 3.28 & 0.14 & $\mathrm{Q}$ \\
\hline Fat yield, kg/d & 1.172 & 1.256 & 1.180 & 1.205 & 0.07 & NS \\
\hline $3.5 \% \mathrm{FCM}, \mathrm{kg} / \mathrm{d}$ & 34.6 & 36.5 & 34.5 & 35.4 & 1.5 & NS \\
\hline Protein, \% & 2.78 & 2.86 & 2.81 & 2.82 & 0.06 & NS \\
\hline Protein, kg/d & 0.999 & 1.082 & 0.990 & 1.036 & 0.038 & $\mathrm{C}$ \\
\hline Lactose, \% & 4.79 & 4.78 & 4.68 & 4.73 & 0.07 & NS \\
\hline SNF, $\%$ & 8.38 & 8.43 & 8.29 & 8.35 & 0.10 & NS \\
\hline $\mathrm{SCC}, 1000 / \mathrm{mL}$ & 218 & 172 & 211 & 174 & 60 & $\mathrm{Q}$ \\
\hline \multicolumn{7}{|c|}{ Trial 4 (alfalfa:corn silage ratio $=25: 75)$} \\
\hline Milk, kg/d & 39.2 & 38.5 & 39.1 & 39.3 & 1.2 & NS \\
\hline Fat, \% & 3.71 & 3.51 & 3.60 & 3.64 & 0.13 & NS \\
\hline Fat yield, kg/d & 1.454 & 1.347 & 1.434 & 1.398 & 0.06 & $\mathrm{C}$ \\
\hline $3.5 \%$ FCM, kg/d & 40.6 & 38.4 & 40.5 & 39.4 & 1.4 & $\mathrm{C}$ \\
\hline Protein, \% & 2.98 & 3.00 & 2.98 & 2.93 & 0.08 & $\mathrm{~L}, \mathrm{Q}$ \\
\hline Protein, kg/d & 1.141 & 1.164 & 1.171 & 1.137 & 0.03 & Q \\
\hline Lactose, \% & 4.70 & 4.69 & 4.67 & 4.67 & 0.05 & NS \\
\hline $\mathrm{SNF}, \%$ & 8.49 & 8.45 & 8.46 & 8.42 & 0.10 & NS \\
\hline $\mathrm{SCC}, 1000 / \mathrm{mL}$ & 494 & 324 & 422 & 506 & 190 & NS \\
\hline
\end{tabular}

${ }^{1} \mathrm{NS}=$ Not significant, $\mathrm{L}=$ linear effect, $\mathrm{Q}=$ quadratic effect, $\mathrm{C}=$ cubic effect, all at $P<0.05$, unless specified.

${ }^{2}$ Linear effect at $P<0.10$.

ments. Similarly, small differences in milk protein yield were observed in trials 3 and 4 . Overall, changes in milk fat and protein were small and inconsistent, agreeing with the literature (Leonardi et al., 2003). Kung and Huber (1983) reported no change in milk fat or protein concentration with diets varying in protein from 11 to $17 \%$, whereas Cunningham et al. (1996) showed increased milk fat and protein percentages and yields when dietary protein was increased from 14.5 to $16.5 \%$, but no changes when protein was further increased to 18.5\%. Similarly, Wattiaux and Karg (2004a) reported similar milk fat and protein concentrations whether dietary protein was 16.5 or $19.4 \%$. Sutton (1989) indicated that dietary protein has only small effects on milk fat and protein concentrations. Milk lactose and SNF concentrations were not affected by dietary protein amount. The SCC varied greatly, and was greater than $700 \times 10^{3}$ in some cases in trials 1 and 2 . The variability was caused by 3 or 4 cows in these trials and associated with low milk yields for some of the cows. The influence, however, did not affect treatment effect in the Latinsquare experiments, although it could cause a bias if trials are compared.

Milk urea $\mathrm{N}$ concentration increased linearly $(P<$ 0.01 ) with dietary protein in all 4 trials, and also in a quadratic fashion $(P<0.001)$ in trial 4 (Table 8). Diets used in trial 2 contained less protein than those used in the other trials, resulting in the lowest MUN and 
Table 8. Milk urea $\mathrm{N}$ and blood urea $\mathrm{N}$ (BUN) concentrations of cows fed diets containing different amounts of protein in trials utilizing different ratios of alfalfa to corn silage.

\begin{tabular}{|c|c|c|c|c|c|c|}
\hline \multirow[b]{2}{*}{ Item } & \multicolumn{4}{|c|}{ Dietary treatment (CP \%) } & \multirow[b]{2}{*}{ SEM } & \multirow[b]{2}{*}{ Effect } \\
\hline & 15.00 & 16.25 & 17.50 & 18.75 & & \\
\hline & & & - $(\mathrm{n}$ & L) & & \\
\hline \multicolumn{7}{|c|}{ Trial 1 (alfalfa:corn silage ratio $=100: 0)$} \\
\hline MUN & 9.8 & 10.2 & 11.8 & 13.3 & 0.7 & $\mathrm{~L}$ \\
\hline BUN & 10.3 & 11.7 & 11.5 & 13.8 & 0.6 & $\mathrm{~L}$ \\
\hline \multicolumn{7}{|c|}{ Trial 2 (alfalfa:corn silage ratio $=75: 25$ ) } \\
\hline MUN & 6.2 & 6.8 & 8.5 & 9.9 & 0.5 & $\mathrm{~L}$ \\
\hline BUN & 7.8 & 8.4 & 10.1 & 12.3 & 0.5 & $\mathrm{~L}$ \\
\hline \multicolumn{7}{|c|}{ Trial 3 (alfalfa:corn silage ratio $=50: 50)$} \\
\hline MUN & 12.4 & 13.1 & 12.7 & 13.6 & 0.5 & $\mathrm{~L}$ \\
\hline BUN & 10.3 & 11.1 & 12.4 & 13.9 & 0.3 & $\mathrm{~L}$ \\
\hline \multicolumn{7}{|c|}{ Trial 4 (alfalfa:corn silage ratio $=25: 75$ ) } \\
\hline MUN & 10.8 & 13.2 & 14.4 & 14.9 & 0.7 & $\mathrm{~L}, \mathrm{Q}$ \\
\hline BUN & 11.2 & 12.6 & 14.1 & 15.4 & 0.4 & $\mathrm{~L}$ \\
\hline
\end{tabular}

${ }^{1} \mathrm{~L}=$ Linear effect, $\mathrm{Q}=$ quadratic effect, both at $P<0.001$ for all measurements except for MUN in trial 3 , which was at $P<0.005$.

blood urea $\mathrm{N}$ concentrations. Moreover, the concentrations in that trial showed a response to increased dietary protein. This occurred despite the high intake of $\mathrm{N}$ due to high DMI, as discussed below. Evidently, high feed intake decreased nutrient digestibility and resulted in no net increase in absorbed N. Kohn et al. (2002) suggested that MUN be targeted at 8.5 to 11.5 $\mathrm{mg} / \mathrm{dL}$. Most of the MUN values for the 2 lower protein diets of the trials were below the upper threshold, and most of the values for the 2 higher protein diets were above the upper threshold. Analysis of combined data from all trials showed that MUN linearly increased from 9.9 to $13.1 \mathrm{mg} / \mathrm{dL}$ (SEM 0.3) and blood urea $\mathrm{N}$ from 9.9 to $13.8 \mathrm{mg} / \mathrm{dL}$ (SEM 0.3 ) as dietary protein was increased from the lowest to the highest levels. These changes are consistent with changes in urinary $\mathrm{N}$ concentration, as discussed below. The observation on the relationship between dietary protein level and MUN and blood urea $\mathrm{N}$ concentrations is also consistent with those made in many other studies (Broderick and Clayton, 1997; Chapa et al., 2001; Sannes et al., 2002). Because of the close relationship, models have been developed to evaluate $\mathrm{N}$ utilization based on MUN (Jonker et al., 1998; Kauffman and St-Pierre, 2001; Kohn et al., 2002), and the relevance of the application was recently discussed in depth by Wattiaux and Karg (2004a).

\section{Nutrient Digestibility}

Apparent digestibility of DM increased linearly $(P<$ $0.001)$ as the protein content of the diet was increased in trials 2 and 4, and changed in linear and quadratic ways $(P<0.05)$ in trials 1 and 3 (Table 9$)$. The highest digestibility occurred with the $16.25 \% \mathrm{CP}$ treatment in trial 1, and with the $15.00 \% \mathrm{CP}$ treatment in trial 3 . The digestibility was low for all diets in trial 2 , associated with high DMI. Overall, changes in DM digestibility with dietary protein level were inconsistent, as it has been in the literature. Cunningham et al. (1996) reported similar OM digestibility when diets contained 14.5 to $18.5 \%$ CP, and Wattiaux and Karg (2004b) showed no changes in DM digestibility when dietary protein was changed from 16.5 to $17.7 \%$. Changes in the apparent digestibility of protein were not consistent either. The change was quadratic in response to increases in dietary protein in trials 1 and 3 , with values being highest for the 2 intermediate protein diets in trial 1, but lowest for these diets in trial 3. On the other hand, the digestibility linearly increased with increasing dietary protein in trials 2 and 4 (there was also a quadratic effect in trial 4), whereas the dietary protein levels of all diets were low in trial 2 , and the levels in trial 4 were similar to those in trial 1 and higher than in trial 3. In the literature, the effect of dietary protein content on protein apparent digestibility has been inconsistent. Decreasing dietary protein has been reported to result in decreases (Wright et al., 1998; Kauffman and St-Pierre, 2001; Broderick, 2003; Wattiaux and Karg, 2004b) or no changes (Noftsger and St-Pierre, 2003) in protein apparent digestibility. The apparent digestibility of $\mathrm{ADF}$ was not affected by dietary protein in trial 1 , but linearly increased with dietary protein in trials 2 and 4 . The effect was quadratic in trial 3 . It should be indicated that as the protein level of the diet was varied in each trial, the proportions of corn, soybeans, and soybean meal in the diet were adjusted, and that may have influenced nutrient digestibility, thus confounding the effect of protein concentration. 
Table 9. Apparent digestibility of nutrients in cows fed diets containing different amounts of protein in trials utilizing different ratios of alfalfa to corn silage.

\begin{tabular}{|c|c|c|c|c|c|c|}
\hline \multirow[b]{2}{*}{ Item } & \multicolumn{4}{|c|}{ Dietary treatment (CP \%) } & \multirow[b]{2}{*}{ SEM } & \multirow[b]{2}{*}{ Effect $^{1}$} \\
\hline & 15.00 & 16.25 & 17.50 & 18.75 & & \\
\hline \multirow{2}{*}{\multicolumn{7}{|c|}{ Trial 1 (alfalfa:corn silage ratio $=100: 0)$}} \\
\hline & & & & & & \\
\hline DM & 60.9 & 62.6 & 60.3 & 57.6 & 0.9 & $\mathrm{~L}, \mathrm{Q}$ \\
\hline $\mathrm{CP}$ & 55.8 & 59.1 & 58.2 & 56.4 & 1.2 & $\mathrm{Q}$ \\
\hline $\mathrm{ADF}$ & 40.1 & 41.8 & 38.8 & 39.5 & 2.1 & NS \\
\hline \multicolumn{7}{|c|}{ Trial 2 (alfalfa:corn silage ratio $=75: 25)$} \\
\hline DM & 48.2 & 51.5 & 53.9 & 54.9 & 1.2 & $\mathrm{~L}$ \\
\hline $\mathrm{CP}$ & 44.9 & 48.0 & 51.5 & 53.5 & 1.5 & $\mathrm{~L}$ \\
\hline $\mathrm{ADF}$ & 31.3 & 33.3 & 36.5 & 36.9 & 1.5 & $\mathrm{~L}$ \\
\hline \multicolumn{7}{|c|}{ Trial 3 (alfalfa:corn silage ratio $=50: 50)$} \\
\hline DM & 66.5 & 62.9 & 60.4 & 63.2 & 1.2 & $\mathrm{~L}, \mathrm{Q}$ \\
\hline $\mathrm{CP}$ & 62.5 & 61.3 & 60.8 & 65.1 & 1.3 & Q \\
\hline $\mathrm{ADF}$ & 47.0 & 42.2 & 40.0 & 43.9 & 1.8 & Q \\
\hline \multicolumn{7}{|c|}{ Trial 4 (alfalfa:corn silage ratio $=25: 75$ ) } \\
\hline DM & 61.5 & 67.3 & 67.5 & 68.7 & 1.2 & $\mathrm{~L}$ \\
\hline $\mathrm{CP}$ & 58.2 & 67.8 & 68.8 & 71.8 & 1.3 & $\mathrm{~L}, \mathrm{Q}$ \\
\hline $\mathrm{ADF}$ & 37.2 & 46.0 & 47.3 & 51.3 & 1.9 & $\mathrm{~L}$ \\
\hline
\end{tabular}

${ }^{1} \mathrm{NS}=$ No significant effect, $\mathrm{L}=$ linear effect, $\mathrm{Q}=$ quadratic effect, all at $P<0.05$.

\section{Nitrogen Excretion}

Fecal and urinary $\mathrm{N}$ concentrations increased linearly as dietary protein was increased for all trials (Table 10). When data were combined across trials, fecal $\mathrm{N}$ linearly increased from 2.8 to $3.0 \%$ (SEM $0.02, P<$ 0.001 ), and urinary $\mathrm{N}$ from 5.8 to $7.3 \mathrm{~g} / \mathrm{L}$ (SEM $0.1, P$ $<0.001$ ), as dietary protein was increased from the lowest to the highest concentrations. The result on urinary $\mathrm{N}$ concentration is consistent with several other studies that reported increased urinary $\mathrm{N}$ excretion with increased dietary protein (Tomlinson et al., 1996; Castillo et al., 2001).
Estimated urine volume increased linearly with dietary protein in all trials (Table 10), as expected based on established relationships (Bannink et al., 1999). Averaged across trials, the increase was $1.5 \mathrm{~L} / \mathrm{d}$ for every 1 percentage-unit-increase in dietary protein compared to $2 \mathrm{~L} / \mathrm{d}$ measured by Dinn et al. (1998) and $4 \mathrm{~L} / \mathrm{d}$ by Wattiaux and Karg (2004b) through total collection. The volume appeared lowest in trial 2 , consistent with the protein content of the diet. The $\mathrm{K}$ content of the diet increased, whereas the content of $\mathrm{Na}$ remained relatively constant, as protein was increased in each trial (Tables 1 to 4), probably having contributed to

Table 10. Fecal and urinary $\mathrm{N}$ concentrations and estimated urine volume in cows fed diets containing different amounts of protein in trials utilizing different ratios of alfalfa to corn silage.

\begin{tabular}{lcccccc}
\hline & \multicolumn{3}{c}{ Dietary treatment (CP \%) } & & \\
\cline { 2 - 5 } & 15.00 & 16.25 & 17.50 & 18.75 & SEM & Effect $^{1}$ \\
Item & & & & & & \\
Trial 1 (alfalfa:corn silage ratio = 100:0) & 3.03 & 3.09 & 3.18 & 3.29 & 0.05 & $\mathrm{~L}$ \\
$\quad$ Fecal N, \% & 6.29 & 6.79 & 6.92 & 7.28 & 0.33 & $\mathrm{~L}$ \\
$\quad$ Urinary N, g/L & 36.4 & 38.9 & 37.1 & 42.9 & 1.8 & $\mathrm{~L}$ \\
$\quad$ Urine, L/d & & & & & & \\
Trial 2 (alfalfa:corn silage ratio = 75:25) & 2.47 & 2.69 & 2.83 & 2.95 & 0.04 & $\mathrm{~L}$ \\
$\quad$ Fecal N, \% & 5.17 & 5.55 & 6.66 & 7.44 & 0.29 & $\mathrm{~L}$ \\
$\quad$ Urinary N, g/L & 24.9 & 25.0 & 27.4 & 27.8 & 1.3 & $\mathrm{~L}$ \\
$\quad$ Urine, L/d & 2.81 & 2.81 & 2.82 & 2.89 & 0.03 & $\mathrm{~L}$ \\
Trial 3 (alfalfa:corn silage ratio = 50:50) & 5.86 & 6.16 & 6.60 & 7.54 & 0.31 & $\mathrm{~L}$ \\
$\quad$ Fecal N, \% & 37.5 & 38.2 & 39.4 & 43.3 & 2.4 & $\mathrm{~L}$ \\
$\quad$ Urinary N, g/L & & & & & & \\
$\quad$ Urine, L/d & 2.80 & 2.74 & 2.84 & 2.87 & 0.03 & $\mathrm{~L}$ \\
Trial 4 (alfalfa:corn silage ratio = 25:75) & 5.91 & 5.81 & 6.29 & 6.59 & 0.23 & $\mathrm{~L}$ \\
$\quad$ Fecal N, \% & 37.4 & 41.0 & 40.7 & 43.7 & 1.8 & $\mathrm{~L}$ \\
$\quad$ Urinary N, g/L & & & & &
\end{tabular}

\footnotetext{
${ }^{1} \mathrm{~L}=$ Linear effect at $P<0.05$.
} 
Table 11. Nitrogen utilization by cows fed diets containing different amounts of protein in trials utilizing different ratios of alfalfa to corn silage.

\begin{tabular}{|c|c|c|c|c|c|c|}
\hline \multirow[b]{2}{*}{ Item } & \multicolumn{4}{|c|}{ Dietary treatment (CP \%) } & \multirow[b]{2}{*}{ SEM } & \multirow[b]{2}{*}{ Effect $^{1}$} \\
\hline & 15.00 & 16.25 & 17.50 & 18.75 & & \\
\hline \multicolumn{7}{|c|}{ Trial 1 (alfalfa:corn silage ratio $=100: 0$ ) } \\
\hline Intake $\mathrm{N}, \mathrm{g} / \mathrm{d}$ & 610 & 658 & 684 & 738 & 15 & $\mathrm{~L}$ \\
\hline Fecal N, g/d & 269 & 270 & 285 & 323 & 107 & $\mathrm{~L}$ \\
\hline Absorbed N, g/d & 335 & 395 & 396 & 418 & 12 & $\mathrm{~L}, \mathrm{Q}$ \\
\hline Urinary $\mathrm{N}, \mathrm{g} / \mathrm{d}$ & 229 & 256 & 252 & 310 & 15 & $\mathrm{~L}$ \\
\hline Fecal N/intake N, \% & 44.2 & 40.9 & 41.8 & 43.6 & 1.2 & $\mathrm{Q}$ \\
\hline Urinary N/intake N, \% & 38.2 & 39.6 & 37.3 & 42.5 & 2.6 & NS \\
\hline Urinary N/excreted N, \% & 45.3 & 48.8 & 46.4 & 49.0 & 1.7 & NS \\
\hline Milk N/intake N & 0.26 & 0.24 & 0.24 & 0.22 & 0.01 & $\mathrm{~L}$ \\
\hline Milk N/absorbed N & 0.47 & 0.40 & 0.41 & 0.39 & 0.02 & $\mathrm{~L}$ \\
\hline \multicolumn{7}{|c|}{ Trial 2 (alfalfa:corn silage ratio $=75: 25)$} \\
\hline Intake $\mathrm{N}, \mathrm{g} / \mathrm{d}$ & 669 & 712 & 800 & 827 & 21 & $\mathrm{~L}$ \\
\hline Fecal N, g/d & 369 & 370 & 386 & 382 & 14 & NS \\
\hline Absorbed N, g/d & 296 & 339 & 416 & 448 & 14 & $\mathrm{~L}$ \\
\hline Urinary $\mathrm{N}, \mathrm{g} / \mathrm{d}$ & 127 & 139 & 177 & 204 & 7 & $\mathrm{~L}$ \\
\hline Fecal N/intake N, \% & 55.1 & 52.0 & 48.5 & 46.5 & 1.3 & $\mathrm{~L}$ \\
\hline Urinary N/intake N, \% & 19.1 & 20.1 & 22.5 & 25.2 & 1.0 & $\mathrm{~L}$ \\
\hline Urinary N/excreted N, \% & 25.8 & 27.6 & 31.4 & 34.8 & 1.0 & $\mathrm{~L}$ \\
\hline Milk N/intake N & 0.26 & 0.24 & 0.22 & 0.21 & 0.01 & $\mathrm{~L}$ \\
\hline Milk N/absorbed N & 0.58 & 0.49 & 0.42 & 0.40 & 0.02 & $\mathrm{~L}$ \\
\hline \multicolumn{7}{|c|}{ Trial 3 (alfalfa:corn silage ratio $=50: 50$ ) } \\
\hline Intake $\mathrm{N}, \mathrm{g} / \mathrm{d}$ & 614 & 671 & 684 & 751 & 13 & $\mathrm{~L}$ \\
\hline Fecal N, g/d & 229 & 259 & 273 & 264 & 11 & $\mathrm{~L}, \mathrm{Q}$ \\
\hline Absorbed N, g/d & 382 & 409 & 414 & 490 & 11 & $\mathrm{~L}, \mathrm{Q}$ \\
\hline Urinary $\mathrm{N}, \mathrm{g} / \mathrm{d}$ & 204 & 225 & 246 & 288 & 11 & $\mathrm{~L}$ \\
\hline Fecal N/intake N, \% & 37.5 & 38.7 & 39.2 & 34.9 & 1.3 & $\mathrm{Q}$ \\
\hline Urinary N/intake N, \% & 33.9 & 33.6 & 36.3 & 38.2 & 1.7 & $\mathrm{~L}$ \\
\hline Urinary N/excreted N, \% & 47.6 & 46.7 & 47.2 & 52.4 & 1.4 & $\mathrm{~L}, \mathrm{Q}$ \\
\hline Milk N/intake N & 0.28 & 0.25 & 0.24 & 0.22 & 0.01 & $\mathrm{~L}$ \\
\hline Milk N/absorbed N & 0.44 & 0.40 & 0.39 & 0.34 & 0.02 & $\mathrm{~L}$ \\
\hline \multicolumn{7}{|c|}{ Trial 4 (alfalfa:corn silage ratio $=25: 75$ ) } \\
\hline Intake $\mathrm{N}, \mathrm{g} / \mathrm{d}$ & 676 & 723 & 763 & 809 & 22 & $\mathrm{~L}$ \\
\hline Fecal N, g/d & 283 & 238 & 240 & 224 & 13 & $\mathrm{~L}$ \\
\hline Absorbed N, g/d & 390 & 494 & 521 & 591 & 18 & $\mathrm{~L}$ \\
\hline Urinary $\mathrm{N}, \mathrm{g} / \mathrm{d}$ & 236 & 231 & 247 & 276 & 10 & $\mathrm{~L}, \mathrm{Q}$ \\
\hline Fecal N/intake N, \% & 41.8 & 32.2 & 31.2 & 28.2 & 1.3 & $\mathrm{~L}, \mathrm{Q}$ \\
\hline Urinary N/intake N, \% & 35.2 & 32.1 & 33.0 & 34.3 & 1.3 & $\mathrm{Q}$ \\
\hline Urinary N/excreted N, \% & 44.8 & 49.8 & 51.3 & 55.5 & 1.3 & $\mathrm{~L}$ \\
\hline Milk N/intake N & 0.28 & 0.25 & 0.24 & 0.22 & 0.01 & $\mathrm{~L}$ \\
\hline Milk N/absorbed N & 0.48 & 0.37 & 0.36 & 0.31 & 0.01 & $\mathrm{~L}$ \\
\hline
\end{tabular}

${ }^{1} \mathrm{NS}=$ No significant effect, $\mathrm{L}=$ linear effect, $\mathrm{Q}=$ quadratic effect, all at $P<0.05$.

the increases in urinary output (Bannink et al., 1999; Valadares et al., 1999). However, that effect would be small, because the change in $\mathrm{K}$ concentration was slight (from 1.05 to $1.21 \%$ for the lowest to the highest protein diets on average across trials). Urinary volume was estimated from creatinine excretion, which has been reported to be unaffected by diets (Valadares et al., 1999). Calculated creatinine excretion was 19.7 to 21.9 g/d, compared with 18.0 to $18.9 \mathrm{~g} / \mathrm{d}$ obtained by Valadares et al. (1999). Valadares et al. (1999) and Leonardi et al. (2003) reported no difference in urine volume estimated using creatinine and measured by total collection.

The intake of $\mathrm{N}$ increased linearly $(P<0.001)$ as the protein content of the diet was increased for all trials (Table 11). The increase in $\mathrm{N}$ intake from the lowest to the highest protein diets ranged from 128 to $158 \mathrm{~g} / \mathrm{d}$ across trials, resulting in an average increment from one dietary protein level to the next ranging from 43 to $53 \mathrm{~g} / \mathrm{d}$. Among trials, $\mathrm{N}$ intake was lower in trials 1 and 3 than in trials 2 and 4 . Excretion of $\mathrm{N}$ in feces increased linearly as the protein content of the diet was increased in trials 1 and 3 , and in a quadratic manner in trial 3. However, fecal $\mathrm{N}$ excretion did not change in trial 2, and decreased as the diet was changed from the lowest protein level to the other levels in trial 4 . Although consistent with some studies (Wright et al., 1998; Kauffman and St-Pierre, 2001; Broderick, 2003), the surprising decrease in apparent digestibility of protein for the lowest protein diet in trial 4 (Table 9) resulted in the increased fecal $\mathrm{N}$ excretion. Covarianceadjusted least square means for absorbed $\mathrm{N}$ (intake $\mathrm{N}$ - 
fecal N) increased as more protein was consumed in all trials. Excretion of $\mathrm{N}$ in urine increased linearly as the protein content of the diet was increased in all trials. The average increment in urinary $\mathrm{N}$ excretion was $24 \mathrm{~g} /$ $\mathrm{d}$ for every 1-percentage-unit increase in dietary protein based on treatment means of all trials, compared to 27 g/d reported by Cressmann et al. (1980). Broderick and Radloff (2004) suggested that, although satisfactory, fecal and urinary $\mathrm{N}$ excretion estimated using markers and spot sampling is likely to be less accurate than direct measurements by total collection. This may have contributed to the variation in the estimated $\mathrm{N}$ excretion values. Conversion of intake $\mathrm{N}$ and absorbed $\mathrm{N}$ to milk $\mathrm{N}$ decreased linearly as the protein content of the diet was increased in all trials. All trials combined, total $\mathrm{N}$ excretion (fecal and urinary) linearly increased from 484 to $571 \mathrm{~g} / \mathrm{d}$ (SEM 9), or by $18 \%$, as dietary protein was increased from the lowest to the highest concentrations. In the meantime, conversion of intake $\mathrm{N}$ to milk $\mathrm{N}$ linearly decreased from 0.27 to 0.22 (SEM 0.01 ), by $19 \%$. This resulted in an average change of $18 \%$ based on $\mathrm{N}$ excretion and utilization. These data, as well as those on fecal and urinary $\mathrm{N}$ concentrations (Table 10), suggested that, overall, as the intake of $\mathrm{N}$ increased more $\mathrm{N}$ was excreted, resulting in decreased efficiency of $\mathrm{N}$ utilization.

The distribution of fecal $\mathrm{N}$ and urinary $\mathrm{N}$ is particularly interesting. Of the 2 routes, fecal $\mathrm{N}$ appeared to account for a larger proportion of intake $\mathrm{N}$ than did urinary $\mathrm{N}$ in most of the cases except for the highest protein diet in trial 3 and the 2 higher protein diets in trial 4 (Table 11). The observation is consistent with those of Kauffman and St-Pierre (2001), Broderick (2003), and Broderick and Radloff (2004), but not that of Wattiaux and Karg (2004b), who obtained approximately $70 \% \mathrm{DM}$ digestibility with their diets. The proportion values for urinary $\mathrm{N}$ were low for trial 2 , ranging from 19 to $25 \%$ among treatments. Similarly, the proportion of total $\mathrm{N}$ excreted as urinary $\mathrm{N}$ was low for trial 2 , ranging from 25 to $35 \%$ among treatments, compared with $>45 \%$ for other trials. To make a comparison, urinary $\mathrm{N}$ was also estimated using the method described by Kohn et al. (2002) based on BW and MUN, and by difference using the equation of intake $\mathrm{N}-$ fecal $\mathrm{N}-$ milk N. Averages across treatments were larger for the reported values (Table 11) than those obtained with BW and MUN for all trials except for trial 4, and lower for the reported values than those obtained using the difference method for all trials except for trial 1. Across treatments and trials, the averages were reasonably compatible, being 238,221 , and $270 \mathrm{~g} / \mathrm{d}$ for the reported values, the values estimated from BW and MUN, and the values estimated by difference, respectively.

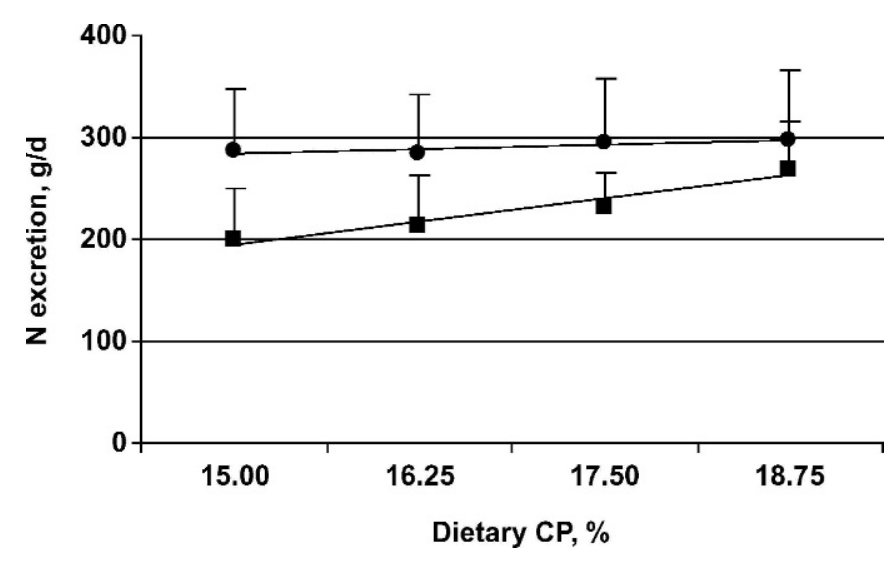

Figure 1. Fecal $(\bullet)$ and urinary $(\square) \mathrm{N}$ excretion with different dietary protein treatments. Bars represent the standard deviation of the means.

Urinary $\mathrm{N}$ excretion increased more rapidly than did fecal $\mathrm{N}$ as dietary protein was increased, as illustrated in Figure 1, using treatment means when data were combined across trials. Obtained in the same way, the proportion of the total $\mathrm{N}$ excreted as urinary $\mathrm{N}$ linearly increased from 41 to $48 \%$ (SEM 0.7) as dietary protein was increased from the lowest to the highest concentrations. Increased urinary $\mathrm{N}$ excretion resulted from increases in both urinary volume and urinary $\mathrm{N}$ concentration. This pattern of change in fecal and urinary $\mathrm{N}$ excretion is consistent with observations made in many other studies utilizing different dietary protein concentrations. For example, when dietary protein was increased from 13 to $17 \%$ (Kauffman and St-Pierre, 2001) and from 15 to $16.5 \%$ (Broderick, 2003), both fecal and urinary $\mathrm{N}$ excretions increased. However, when dietary protein was changed at higher levels, from 16.7 to $18.4 \%$ (Broderick, 2003), from 16.5 to $19.4 \%$ (Davidson et al., 2003), from 16.5 to $17.7 \%$ (Wattiaux and Karg, 2004b), and from 17.0 to $18.4 \%$ (Noftsger and St-Pierre, 2003), only urinary $\mathrm{N}$ excretion increased. This suggests that feeding protein in excess of requirements not only increases total $\mathrm{N}$ excretion, but also increases the risk of $\mathrm{N}$ loss to the environment, because urine is more labile than fecal N (Varel et al., 1999).

\section{Adequate Protein Amount}

Protein utilization in this study was further assessed with the $2001 \mathrm{NRC}$ ration formulation program using treatment means for DMI and milk yield, and Table 12 lists the averages for each dietary protein treatment across trials. Predicted balance in RDP, RUP, and metabolizable protein between the amount supplied and the amount needed for observed milk yields all in- 
Table 12. Averages of predictions across trials for each dietary protein level by using NRC (2001) using treatment means for DMI and milk production measurements. ${ }^{1}$

\begin{tabular}{lcccc}
\hline & \multicolumn{3}{c}{ Dietary treatment $(\mathrm{CP} \%)$} \\
\cline { 2 - 5 } Item & 15.00 & 16.25 & 17.50 & 18.75 \\
\hline Average dietary CP based on analysis, $\%$ & 15.7 & 16.9 & 18.0 & 19.2 \\
MP $^{2}$ balance, ${ }^{3} \mathrm{~g} / \mathrm{d}$ & -22 & 82 & 185 & 283 \\
RDP balance, ${ }^{3} \mathrm{~g} / \mathrm{d}$ & 162 & 335 & 509 & 677 \\
RUP balance, ${ }^{3} \mathrm{~g} / \mathrm{d}$ & -31 & 107 & 244 & 375 \\
Milk yield, $\mathrm{kg} / \mathrm{d}$ & & & 42.4 & 42.6 \\
NE & 41.5 & 42.0 & 40.0 & 41.7 \\
MP allowable & 35.4 & 37.7 & 35.7 & 36.3 \\
Observed & 35.5 & 35.6 & 35.7 \\
\hline
\end{tabular}

${ }^{1}$ The following treatment means for DMI, milk yield, milk fat, and milk protein were used for trials 1 to 4, respectively: $23.0 \mathrm{~kg} / \mathrm{d}, 32.0 \mathrm{~kg} / \mathrm{d}, 3.74 \%, 3.14 \% ; 29.0 \mathrm{~kg} / \mathrm{d}, 35.5 \mathrm{~kg} / \mathrm{d}, 3.55 \%, 3.03 \% ; 24.4 \mathrm{~kg} / \mathrm{d}, 36.5 \mathrm{~kg} / \mathrm{d}$, $3.30 \%, 2.82 \% ; 26.0 \mathrm{~kg} / \mathrm{d}, 39.0 \mathrm{~kg} / \mathrm{d}, 3.62 \%, 2.97 \%$.

${ }^{2} \mathrm{MP}=$ Metabolizable protein.

${ }^{3}$ Balance between the amount supplied and the amount needed for producing the amount of milk observed.

creased as the dietary protein content was increased. The balance for RUP and metabolizable protein changed from negative to positive values when dietary protein was increased from the lowest level. This suggests that RUP was limiting, whereas RDP was not, with the lowest dietary protein concentration (averaging $15.7 \%$ across trials). Based on the change in predicted metabolizable protein, increasing dietary protein to the next level (averaging 16.9\% across trials) was necessary, but increasing protein further to the levels of the last 2 treatments (averaging 18.0 and $19.2 \%$ ) was not. Observed milk yield was similar to predicted based on metabolizable protein although lower than predicted based on $\mathrm{NE}_{\mathrm{L}}$ for the lowest dietary protein level; however, it was lower than those predicted based on metabolizable protein as well as $\mathrm{NE}_{\mathrm{L}}$ for other dietary protein levels, further suggesting that protein was not limiting at these levels. Because the milk yield allowed by metabolizable protein for the second lowest protein level was $37.7 \mathrm{~kg} / \mathrm{d}$, these predictions suggest that $16 \%$ dietary protein was not sufficient for $38 \mathrm{~kg} / \mathrm{d}$ of milk, but $17 \%$ was sufficient. This assessment agrees with the suggestion that early lactation cows need $17.5 \%$ protein in the diet (Wu and Satter, 2000). Other studies (Sannes et al., 2002; Broderick, 2003; Davidson et al., 2003) also suggested that $17 \%$ protein was sufficient for this level of production.

\section{Further Research}

Although this study showed increased milk yields (Table 7) and decreased total $\mathrm{N}$ excretion, in amount (Figure 2) and as a percentage of intake (Table 11), as the proportion of corn silage in the forage part of the diet increased from trial 1 to trial 4 (alfalfa:corn silage ratio $=100: 0,75: 25,50: 50$, and 25:75 for these trials, respectively), it is difficult to attribute these changes to the forage proportion solely, because the trials were carried out separately. However, the data do suggest that the forage makeup may have an influence on milk production and $\mathrm{N}$ utilization, especially considering the similarity of these trials. Corn silage is a fermentable carbohydrate source, and alfalfa is high in RDP. Together, they provide readily available energy and $\mathrm{N}$ for microbial synthesis in the rumen. Therefore, it is possible that there is a ratio of the 2 forage sources at which the most efficient utilization of $\mathrm{N}$ occurs. Dhiman and Satter (1997) suggested that corn silage should account for one- to two-thirds in the alfalfa and corn silage combination for efficient utilization of N. Wattiaux and Karg (2004b) showed that cows fed corn silage as the major forage source reduced urinary $\mathrm{N}$ more in response to a reduction in dietary protein than did those

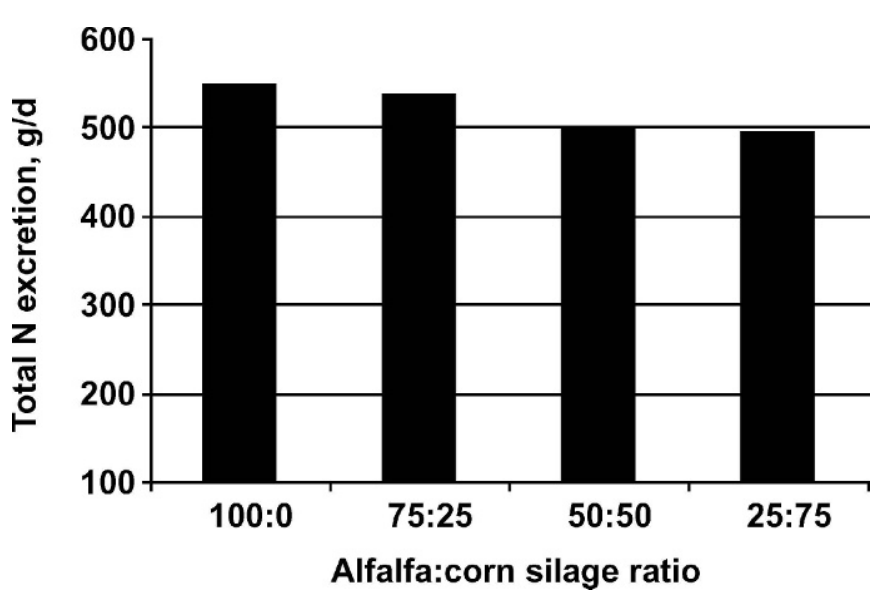

Figure 2. Total $\mathrm{N}$ excretion by cows in trials utilizing different ratios of alfalfa to corn silage. 
fed alfalfa silage. There have also been studies (Charmley et al., 1993; Smith et al., 1993; Onetti et al., 2002) that reported no differences in milk yield using alfalfa or corn silage as the major forage source. It seems desirable to further study the subject of alfalfa:corn silage ratio from the angle of possible interactions with dietary protein amount.

\section{CONCLUSIONS}

Using 4 trials that varied in the proportion of alfalfa and corn silage in the forage part of the diet, varying dietary protein from 15.7 to $19.2 \%$ did not affect milk yield, but increased $\mathrm{N}$ excretion and reduced the efficiency of $\mathrm{N}$ utilization for milk production. Urinary $\mathrm{N}$ accounted for an increasing proportion of the total $\mathrm{N}$ excreted, as more protein was fed. Based on the data from all 4 trials and the evaluation using the NRC (2001) ration formulation program, dietary protein at $17 \%$ was sufficient for cows producing $38 \mathrm{~kg} / \mathrm{d}$ of milk and fed diets containing various proportions of alfalfa and corn silage. Reducing protein to this amount can reduce $\mathrm{N}$ excretion, especially environmentally labile urinary $\mathrm{N}$, without affecting milk production.

\section{ACKNOWLEDGMENTS}

The authors thank employees at the Dairy Cattle Research and Education Center, Pennsylvania State University, for feed preparation and animal care, and K. R. K. Reddy, A. M. Brown, D. J. Burns, and S. K. Tallam for technical support. This work was supported in part from a grant from the USDA National Research Initiative Cooperative Grant Program, award number 2000-04743, Project Director, J. M. Powell, University of Wisconsin, Madison, WI, and a grant in-aid provided by Agway Inc. (Shippensburg, PA).

\section{REFERENCES}

AOAC. 1990. Official Methods of Analysis. 15th ed. Association of Official Analytical Chemists, Arlington, VA.

Bannink, A., H. Valk, and A. M. Van Vuuren. 1999. Intake and excretion of sodium, potassium, and nitrogen and the effects on urine production by lactating dairy cows. J. Dairy Sci. 82:1008-1018

Broderick, G. A. 2003. Effects of varying dietary protein and energy levels on the production of lactating dairy cows. J. Dairy Sci. 86:1370-1381.

Broderick, G. A., and M. K. Clayton. 1997. A statistical evaluation of animal and nutritional factors influencing concentrations of milk urea nitrogen. J. Dairy Sci. 80:2964-2971.

Broderick, G. A., and W. J. Radloff. 2004. Effect of molasses supplementation on the production of lactating dairy cows fed diets based on alfalfa and corn silage. J. Dairy Sci. 87:2997-3009.

Castillo, A. R., E. Kebreab, D. E. Beever, J. H. Barbi, J. D. Sutton, H. C. Kirby, and J. France. 2001. The effect of protein supplementation on nitrogen utilization in lactating dairy cows fed grass silage diets. J. Anim. Sci. 79:247-253.
Chapa, A. M., M. E. McCormick, J. M. Fernandez, D. D. French, J. D. Ward, and J. F. Beatty. 2001. Supplemental dietary protein for grazing dairy cows: Reproduction, condition loss, plasma metabolites, and insulin. J. Dairy Sci. 84:908-916.

Charmley, E., P. H. Robinson, and R. E. McQueen. 1993. Corn or alfalfa as the forage source in predominately silage diets for latelactation dairy cows. Can. J. Anim. Sci. 73:67-77.

Cressmann, S. G., D. G. Grieve, G. K. Macleod, E. E. Wheeler, and L. G. Young. 1980. Influence of dietary protein concentration on milk production of dairy cattle in early lactation. J. Dairy Sci. 63:1839-1847.

Cunningham, K. D., M. J. Cecava, T. R. Johnson, and P. A. Ludden. 1996. Influence of source and amount of dietary protein on milk yield by cows in early lactation. J. Dairy Sci. 79:620-630.

Davidson, S., B. A. Hopkins, D. E. Diaz, S. M. Bolt, C. Brownie, V. Fellner, and L. W. Whitlow. 2003. Effects of amounts and degradability of dietary protein on lactation, nitrogen utilization, and excretion in early lactation Holstein cows. J. Dairy Sci. $86: 1681-1689$.

Dhiman, T. R., and L. D. Satter. 1997. Yield response of dairy cows fed different proportions of alfalfa silage and corn silage. J. Dairy Sci. 80:2069-2082.

Dinn, N. E., J. A. Shelford, and L. J. Fisher. 1998. Use of the Cornell Net Carbohydrate and Protein System and rumen-protected lysine and methionine to reduce nitrogen excretion from lactating dairy cows. J. Dairy Sci. 81:229-237.

Huhtanen, P., K. Kaustell, and S. Jaakkola. 1994. The use of internal markers to predict total digestibility and duodenal flow of nutrients in cattle given six different diets. Anim. Feed Sci. Technol. 48:211-227.

Jonker, J. S., R. A. Kohn, and R. A. Erdman. 1998. Using milk urea nitrogen to predict nitrogen excretion and utilization efficiency in lactating dairy cattle. J. Dairy Sci. 81:2681-2692.

Kalscheur, K. F., J. H. Vandersall, R. A. Erdman, R. A. Kohn, and E. Russek-Cohen. 1999. Effects of dietary crude protein concentration and degradability on milk production responses of early, mid, and late lactation dairy cows. J. Dairy Sci. 82:545-554.

Kauffman, A. J., and N. R. St-Pierre. 2001. The relationship of milk urea nitrogen to urine nitrogen excretion in Holstein and Jersey cows. J. Dairy Sci. 84:2284-2294.

Kohn, R. A., K. F. Kalscheur, and E. Russek-Cohen. 2002. Evaluation of models to estimate urinary nitrogen and expected milk urea nitrogen. J. Dairy Sci. 85:227-233.

Kung, L., Jr., and J. T. Huber. 1983. Performance of high producing cows in early lactation fed protein of varying amounts, sources and degradabilities. J. Dairy Sci. 66:227-234.

Leonardi, C., M. Stevenson, and L. E. Armentano. 2003. Effect of two levels of crude protein and methionine supplementation on performance of dairy cows. J. Dairy Sci. 86:4033-4042.

National Research Council. 2001. Nutrient Requirements of Dairy Cattle. 7th rev. ed. National Academy Press, Washington, DC.

Noftsger, S., and N. R. St-Pierre. 2003. Supplementation of methionine and selection of highly digestible rumen undegradable protein to improve nitrogen efficiency for milk production. J. Dairy Sci. 86:958-969.

Onetti, S. G., R. D. Shaver, M. A. McGuire, D. L. Palmquist, and R. R. Grummer. 2002. Effects of supplemental tallow on performance of dairy cows fed diets with different corn silage:alfalfa silage ratios. J. Dairy Sci. 85:632-641.

Oser, B. L. 1965. Hawk's Physiological Chemistry. 14th ed. McGrawHill, New York, NY.

Sannes, R. A., M. A. Messman, and D. B. Vagnoni. 2002. Form of rumen-degradable carbohydrate and nitrogen on microbial protein synthesis and protein efficiency of dairy cows. J. Dairy Sci. 85:900-908.

SAS Institute. 1999. SAS User's Guide. Statistics, version 8.2 ed. SAS Inst., Inc. Cary, NC.

Smith, W. A., B. Harris, Jr., H. H. Van Horn, and C. J. Wilcox. 1993. Effects of forage type on production of dairy cows supplemented with whole cottonseed, tallow, and yeast. J. Dairy Sci. 76:205-215. 
Susmel, P., B. Stefanon, E. Plazzota, M. Spanguero, and C. R. Mills. 1994. The effect of energy and protein intake on the excretion of purine derivatives. J. Agric. Sci. 123:257-266.

Sutton, J. D. 1989. Altering milk composition by feeding. J. Dairy Sci. 72:2801-2814.

Tomlinson, A. P., W. J. Powers, H. H. Van Horn, R. A. Nordstedt, and C. J. Wilcox. 1996. Dietary protein effects on nitrogen excretion and manure characteristics of lactating cows. Trans. ASAE 39:1441-1448.

Vagnoni, D. B., G. A. Broderick, M. K. Clayton, and R. D. Hatfield. 1997. Excretion of purine derivatives by Holstein cows abomasally infused with incremental amounts of purines. J. Dairy Sci. 80:1695-1702.

Valadares, R. F. D., G. A. Broderick, S. C. Valadares Filho, and M. K. Clayton. 1999. Effect of replacing alfalfa silage with high moisture corn on ruminal protein synthesis estimated from excretion of total purine derivatives. J. Dairy Sci. 82:2686-2696.
Varel, V. H., J. A. Nienaber, and H. C. Freetly. 1999. Conservation of nitrogen in cattle feedlot waste with urease inhibitors. J. Anim. Sci. 77:1162-1168.

Wattiaux, M. A., and K. L. Karg. 2004a. Protein level for alfalfa and corn silage based diets. I. Lactational response and milk urea nitrogen. J. Dairy Sci. 87:3480-3491.

Wattiaux, M. A., and K. L. Karg. 2004b. Protein level for alfalfa and corn silage based diets. II. Nitrogen balance and manure characteristics. J. Dairy Sci. 87:3492-3502.

Wright, T. C., S. Moscardini, P. H. Luimes, and B. W. McBride. 1998. Effects of rumen-undegradable protein and feed intake on nitrogen balance and milk protein production in dairy cows. J. Dairy Sci. 81:784-793.

Wu, Z., and L. D. Satter. 2000. Milk production during the complete lactation of dairy cows fed diets containing different amounts of protein. J. Dairy Sci. 83:1042-1051. 